\title{
Visualizing the Engram: Learning Stabilizes Odor Representations in the Olfactory Network
}

\author{
(1)Amin MD. Shakhawat, ${ }^{1 \star}$ Ali Gheidi, ${ }^{1 \star}$ Qinlong Hou, ${ }^{1}$ Sandeep K. Dhillon, ${ }^{3}$ Diano F. Marrone, ${ }^{3}$ Carolyn W. Harley, ${ }^{2}$ \\ and Qi Yuan ${ }^{1}$ \\ ${ }^{1}$ Division of Biomedical Sciences, Faculty of Medicine, and 2Department of Psychology, Faculty of Science, Memorial University, St. John's, Newfoundland \\ A1B 3V6, Canada, and ${ }^{3}$ Department of Psychology, Faculty of Science, Wilfrid Laurier University, Waterloo, Ontario N2L 3C5, Canada
}

The nature of memory is a central issue in neuroscience. How does our representation of the world change with learning and experience? Here we use the transcription of Arc mRNA, which permits probing the neural representations of temporally separated events, to address this in a well characterized odor learning model. Rat pups readily associate odor with maternal care. In pups, the lateralized olfactory networks are independent, permitting separate training and within-subject control. We use multiday training to create an enduring memory of peppermint odor. Training stabilized rewarded, but not nonrewarded, odor representations in both mitral cells and associated granule cells of the olfactory bulb and in the pyramidal cells of the anterior piriform cortex. An enlarged core of stable, likely highly active neurons represent rewarded odor at both stages of the olfactory network.

Odor representations in anterior piriform cortex were sparser than typical in adult rat and did not enlarge with learning. This sparser representation of odor is congruent with the maturation of lateral olfactory tract input in rat pups. Cortical representations elsewhere have been shown to be highly variable in electrophysiological experiments, suggesting brains operate normally using dynamic and network-modulated representations. The olfactory cortical representations here are consistent with the generalized associative model of sparse variable cortical representation, as normal responses to repeated odors were highly variable $(\sim 70 \%$ of the cells change as indexed by $A r c$ ). Learning and memory modified rewarded odor ensembles to increase stability in a core representational component.

Key words: Arc; olfactory bulb; olfactory learning; piriform cortex

\section{Introduction}

The rat pup odor preference learning model is highly attractive as a tractable model of mammalian associative learning. The rodent pup readily acquires preferences for odors paired with maternal care signals to support maternal recognition (Logan et al., 2012). The conditioned stimulus in this associative model is typically a novel odor, whereas the unconditioned stimulus is provided by norepinephrine (NE) release from the locus ceruleus acting through an ensemble of noradrenergic receptors, the best studied of which is the $\beta$-adrenoceptor (Yuan et al., 2014). This NE release can be induced by tactile stimulation with a brush to mimic maternal care (Rangel and Leon, 1995). A single trial in which pups on peppermint-scented bedding are stimulated creates a preference for peppermint lasting $24 \mathrm{~h}$, whereas multiple trials

\footnotetext{
Received Aug. 14, 2014; revised Sept. 27, 2014; accepted 0ct. 7, 2014.

Author contributions: D.F.M., C.W.H., and Q.Y. designed research; A.MD.S., A.G., Q.H., S.K.D., D.F.M., and Q.Y. performed research; A.MD.S., A.G., and Q.Y. analyzed data; A.MD.S., A.G., C.W.H., and Q.Y. wrote the paper.

This work was supported by a Canadian Institutes of Health Research operating grant (MOP-102624) to Q.Y. and a Natural Sciences and Engineering Research Council discovery grant (06609-2014) to D.F.M. We thank Dr. Jules Dore for assisting in the initial establishment of Arc catFISH used in this study.

*A.MD.S. and A.G. contributed equally to this work.

The authors declare no competing financial interests.

Correspondence should be addressed to Dr. Qi Yuan, Division of Biomedical Sciences, Faculty of Medicine, Memorial University, St. John's, NL A1B 3V6, Canada. E-mail: qi.yuan@med.mun.ca.

DOI:10.1523/JNEUROSCI.3396-14.2014

Copyright $\odot 2014$ the authors $\quad 0270-6474 / 14 / 3415394-08 \$ 15.00 / 0$
}

spaced over days creates more enduring memories (Fontaine et al., 2013).

Cellular events critical for learning have been identified in both the olfactory bulb (OB) and anterior piriform cortex (aPC). Mechanisms for learning include activation of NMDA receptors (NMDARs; Lethbridge et al., 2012; Morrison et al., 2013), L-type calcium channels (Jerome et al., 2012), metabotropic glutamatergic receptors (Rumsey et al., 2001), adrenergic receptors (Sullivan et al., 2000; Harley et al., 2006; Shakhawat et al., 2012; Morrison et al., 2013), and disinhibition (Lethbridge et al., 2012). Intracellular changes critical for learning in the OB include a temporally specific cAMP transient (Cui et al., 2007), activation of protein kinase A (Grimes et al., 2012), phosphorylation of CREB (McLean et al., 1999), and an insertion of AMPA receptors (AMPARs; Cui et al., 2011).

Changes that relate to long-term memory expression are fewer in number. Visualization methods have shown an increase in intrinsic optical signaling (Yuan et al., 2002), an increase in AMPARs at the glomerular level (Cui et al., 2011), and an increase in network strength in the aPC (Fontaine et al., 2013). Electrophysiological methods have shown potentiation of the olfactory nerve to mitral cell synapse in the OB (Yuan and Harley, 2012) and of the lateral olfactory tract mitral cell output to an aPC pyramidal cell synapse (Fontaine et al., 2013; Morrison et al., 2013).

Maintained increases in AMPAR strength, which have been hard to demonstrate with memory in other systems, have been 
clearly seen in this model (Fontaine et al., 2013). The commissural connections are not mature in the 1-week-old rat pup, and thus odor input is lateralized both in the $\mathrm{OB}$ and piriform cortex (Kucharski et al., 1986; Kucharski and Hall, 1987; Fontaine et al., 2013). Taking advantage of this within-animal control, AMPAR changes congruent with memory duration were readily revealed (Fontaine et al., 2013).

In the present study, cellular compartment analysis of temporal activity by fluorescence in situ hybridization (catFISH) of Arc mRNA was used to identify odor ensemble representations in the $\mathrm{OB}$ and $\mathrm{aPC}$ of rat pups that had undergone odor preference training with one naris occluded. The outcomes support current views of cortical representations in mammalian brain and suggest stability of cell participation in representations is the signature feature of learning and memory.

\section{Materials and Methods}

Animals. All experiments with animals were approved by the Animal Care Committee of Memorial University of Newfoundland in compliance with the guidelines of the Canadian Council on Animal Care. Sprague Dawley rat pups of both sexes were used in this study. Dams with pups were housed in a vivarium that was temperature controlled and on a $12 \mathrm{~h} \mathrm{light/dark} \mathrm{cycle.} \mathrm{The} \mathrm{date} \mathrm{of} \mathrm{birth} \mathrm{for} \mathrm{the} \mathrm{pups} \mathrm{was} \mathrm{designated}$ postnatal day $0(\mathrm{P} 0)$.

Early odor preference training. The early odor preference training protocol with single naris occlusion has been established previously (Yuan and Harley, 2012; Fontaine et al., 2013). Rat pups were assigned to one of two conditions: odor paired with stroking $\left(\mathrm{O} / \mathrm{S}^{+}\right)$or odor only $\left(\mathrm{O} / \mathrm{S}^{-}\right)$. Four-day behavioral training was performed from P3 to P6. During training, all pups received left naris occlusion for each session. Nose plugs were constructed from polyethelyne-20 tubing (Yuan and Harley, 2012; Fontaine et al., 2013). Pups were given a sterile $2 \%$ xylocaine gel application on the left naris $5 \mathrm{~min}$ before plug insertion. Pups were left to rest for $5 \mathrm{~min}$ before subsequently being given either $\mathrm{O} / \mathrm{S}^{+}$or $\mathrm{O} / \mathrm{S}^{-}$training. During training, pups were placed on peppermint-scented bedding $(0.3$ $\mathrm{ml}$ of peppermint for $500 \mathrm{ml}$ volume of bedding). Pups in the $\mathrm{O} / \mathrm{S}^{+}$ group were simultaneously stroked with a paint brush $(30 \mathrm{~s}$ stroking interleaved with $30 \mathrm{~s}$ rest) for $10 \mathrm{~min}$. Pups in the $\mathrm{O} / \mathrm{S}^{-}$were placed on peppermint bedding for $10 \mathrm{~min}$ without being stroked. Nose plugs were removed immediately after the training, and pups were returned to the dams.

Tissue collection. On P7, pups were placed into covered plastic jars with charcoal-filtered clean air flow for $1.5 \mathrm{~h}$ before being given two $5 \mathrm{~min}$ odor deliveries separated by 20 min: either $2 \times$ peppermint or peppermint followed by vanillin or $2 \times$ vanillin (Fig. $1 A$ ). For odor delivery, pups were moved to an adjacent covered jar with peppermint or vanillin bedding at the bottom $(0.3 \mathrm{ml}$ of odor extract mixed with $500 \mathrm{ml}$ of normal bedding) and then switched back to the clean-air jar in the 20 min interval. A naive group was used initially to test odor input specificity. Pups in this group were exposed to two different odors without prior training. For this latter experiment (Fig. 1), 1\% peppermint or vanillin odor diluted in mineral oil was delivered through the air-delivery system (Knosys olfactometer) for the 5 min odor periods (Shakhawat et al., 2014).

After the second odor exposure, rats were decapitated, and their brains were flash-frozen in 2-methyl-butane immersed in an ethanol/dry ice slurry. Brains were preserved in a $-80^{\circ} \mathrm{C}$ freezer until being sectioned at $20 \mu \mathrm{m}$ in a cryostat set at $-20^{\circ} \mathrm{C}$. Sections of right hemispheres of the animals in the input specificity study and both hemispheres of pups from all other groups were mounted onto 2\% 3-aminopropyltriethoxysilanetreated slides (Snowcoat; Leica) using OCT compound (Tissue-Tek; Sakura Fintek USA). Each block usually contained four to six brains from a particular experiment so that these brains were processed together. Five to six slides taken evenly through the rostral to caudal range of the $\mathrm{OB}$ and the aPC were used for fluorescent in situ hybridization and stored at $-20^{\circ} \mathrm{C}$.

Fluorescence in situ hybridization. The fluorescence in situ hybridization protocol used was established previously (Guzowski and Worley,
A
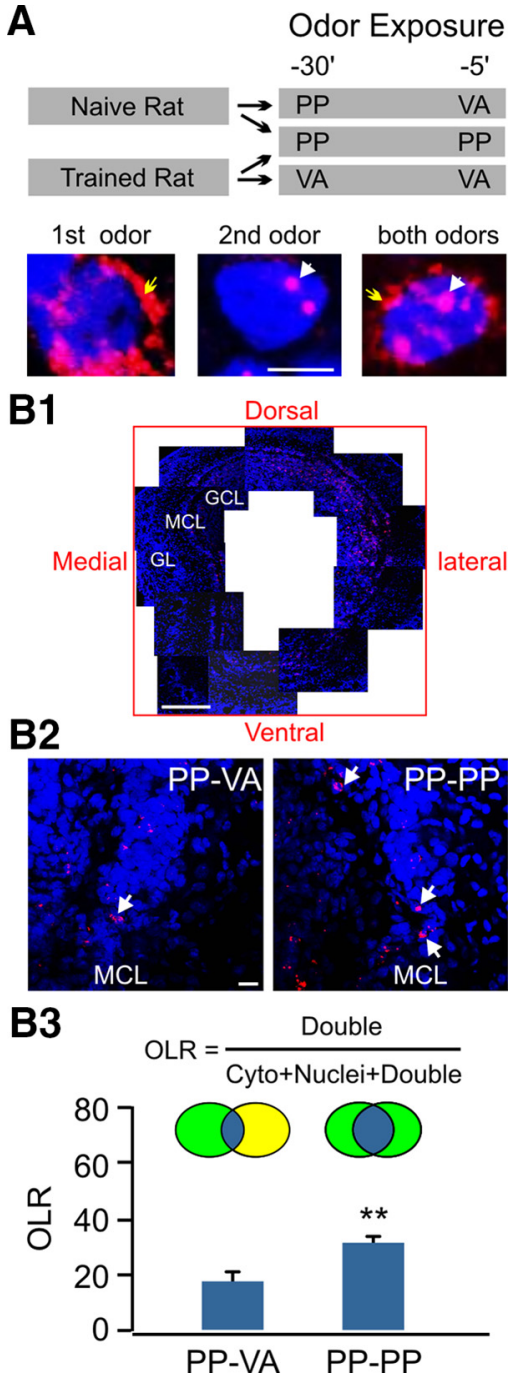

Figure 1. ArcmRNA visualization reveals odor input-specific activation of mitral cell ensembles in the OB. A, Schematic of tissue collection protocols in naive and trained rat pups (top) and example images for $\mathrm{Arc}^{+}$cells (bottom). Blue indicates nuclei staining by DAPI. Red indicates Arc staining. White arrows indicate Arc staining in nuclei. Yellow arrows indicate Arc cytoplasm staining. Scale bar, $10 \mu \mathrm{m}$. B1, Example image of Arc expression in the $\mathrm{OB}$ of a naive rats exposed to $2 \times$ peppermint. $\mathrm{GL}$, Glomerular layer; $\mathrm{MCL}$, mitral cell layer; $\mathrm{GCL}$, granule cell layer. Scale bar, $500 \mu \mathrm{m}$. B2, Example images of dorsolateral OB Arc expression in a naive rat pup to two odor episodes. White arrows indicate $\mathrm{Arc}^{+}$double cells in the MCL. Scale bars, $20 \mu \mathrm{m}$. B3, OLRs of the cell ensembles of the two odor episodes. ${ }^{* *} p<0.01$, PP, Peppermint; VA, vanillin.

2001; Shakhawat et al., 2014). Briefly, Arc full-length DNA plasmid was digested using EcoRI (Invitrogen) and run against a DNA ladder to confirm yield and base pair accuracy $(\sim 2.5 \mathrm{~kb})$. Digoxegenin-labeled riboprobes were synthesized from the digested DNA template using a Maxiscript transcription kit (Ambion). Arc antisense riboprobe yields were confirmed using $1 \%$ agarose gel electrophoresis. Slides were brought to room temperature, fixed with $4 \%$ paraformaldehyde, bathed with acetic anhydride and methanol/acetone (Thermo Fisher Scientific), and treated with prehybridization buffer followed by hybridization buffer (Sigma-Aldrich) and Arc riboprobe. Hybridization occurred overnight in a $56^{\circ} \mathrm{C}$ oven. The next day, after a series of sodium citrate washes, any remaining single-stranded RNA was cleaved using Rnase A (SigmaAldrich) at $37^{\circ} \mathrm{C}$. Endogenous peroxidases were quenched with $\mathrm{H}_{2} \mathrm{O}_{2}$, and slides were blocked with $5 \%$ sheep serum (Sigma-Aldrich) and incubated with anti-digoxegenin-horseradish peroxidase (Roche) for $2 \mathrm{~h}$. After a series of Tris-buffered saline washes, the Cy3 fluorescent marker (PerkinElmer) was applied to visualize $\operatorname{Arc}$ mRNA, and nuclei were counterstained with 4'-6-diamidino-2-phenylindole (DAPI; 1:2000; 
Sigma-Aldrich). Finally, slides were covered with Vectashield antifade medium (Vector Laboratories) and sealed with clear nail polish. Slides were kept at $4^{\circ} \mathrm{C}$ before confocal microscopy scanning.

Confocal image acquisition. Using an FV1000 confocal microscope (Olympus), optical $z$-sections were taken from both the $\mathrm{OB}$ and the aPC. Images of mitral cell layers were taken at $40 \times$ with two standardized areas $\left(\sim 0.06 \mathrm{~mm}^{2}\right.$ each $)$ in the dorsolateral quadrant and two areas in the ventromedial quadrant of the $\mathrm{OB}$ (Fig. $2 A$ ). Images of pyramidal cell layers (II/III) of the aPC were taken at $20 \times$. Two standardizedsized areas $\left(\sim 0.3 \mathrm{~mm}^{2}\right.$ each; one in lateral and one in medial aPC; Fig. $4 A$ ) were scanned. The $z$-stacks (1.0 $\mu \mathrm{m}$ thickness) throughout each section $(20 \mu \mathrm{m})$ of the $\mathrm{OB}$ and the aPC were acquired from three to four slides spread evenly over the rostral to caudal range. Photomultiplier tube assignments, confocal aperture size, and contrast remained constant for each slide. The average counts of the two areas were used for final counts for the dorsolateral and ventromedial $\mathrm{OB}$ and for the $\mathrm{aPC}$.

Image analysis. Off-line image analysis was performed using ImageJ software. The total numbers of DAPI cells were assessed using the Image J automatic cell-counting application for the aPC and the manual counting option for the OB. Foci, cytoplasmic, and double labeling of $\mathrm{Arc}$-positive $\left(\mathrm{Arc}^{+}\right)$cells were counted manually. Labeling of cells as foci, cytoplasmic, and double was achieved by checking multiple optical sections ( $20 \%$ midrange of the $z$-stack) that comprised each individual cell (Miyashita et al., 2009). Counting was performed by an individual blind to all experimental training conditions.

Statistics. OriginPro 9.0 software was used to analyze all data sets. Data were reported as the mean \pm SEM. Two-sample paired $t$ tests were used for statistical comparisons for all experiments except for the input specificity experiment in Figure 1 and the comparison of occluded hemispheres across groups, in which the two-sample unpaired $t$ test was used. Differences between groups were considered significant when $p$ values were $<0.05$.

\section{Results}

The immediate-early gene Arc has been established as a marker to index plasticityrelated neuronal activation in multiple brain areas, including the olfactory cortex (Guzowski et al., 2005; Shakhawat et al., 2014). Although previous research using Northern blots suggested Arc was not expressed early in development in the forebrain (Lyford et al., 1995), the more sensitive in situ hybridization technique readily reveals the presence of Arc mRNA in our study. Arc transcription first appears in the neuronal nucleus within 5 min of neuronal activity. Thirty minutes later, initial Arc mRNA has trans-located to the cytoplasm, and a second event can initiate new transcription of nuclear $\operatorname{Arc}(\mathrm{Gu}-$ zowski et al., 2005). Therefore, Arc permits discrimination of two separate odor events through analysis of compartmentalized expres-
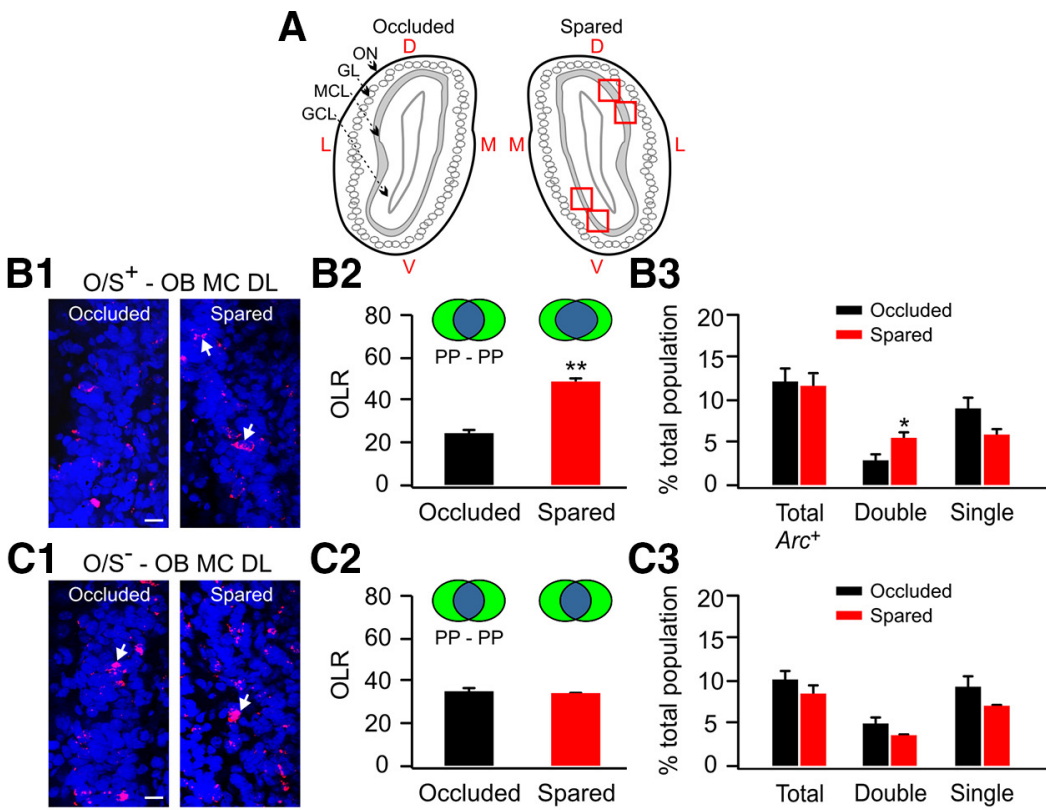

C2

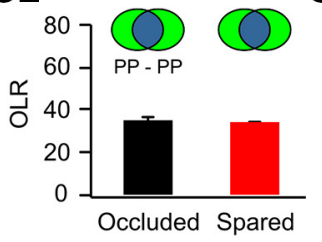

C3
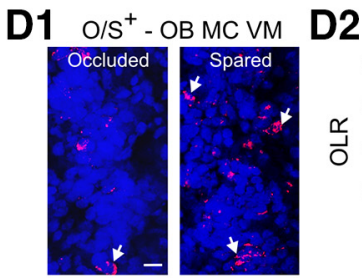

\section{D2}

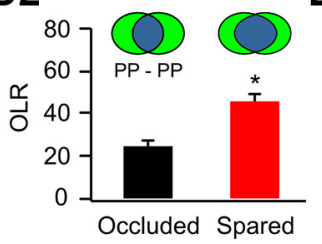

E1 O/S - OB MC VM E2

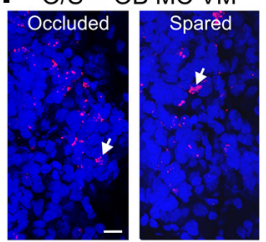

F1
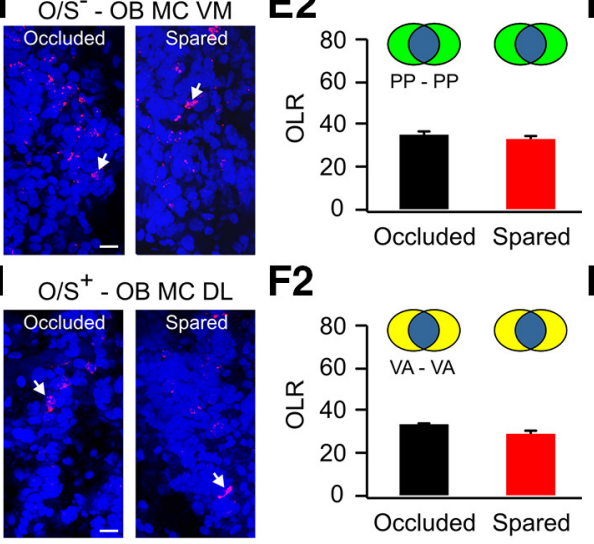

F2

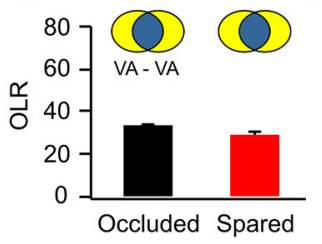

F3

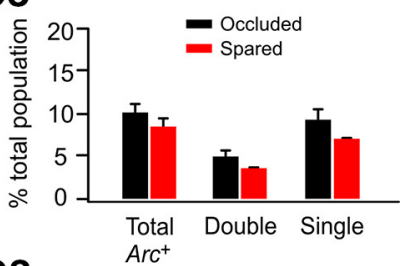

D3

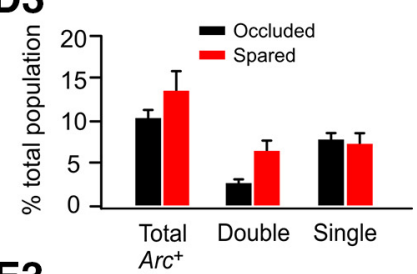

E3
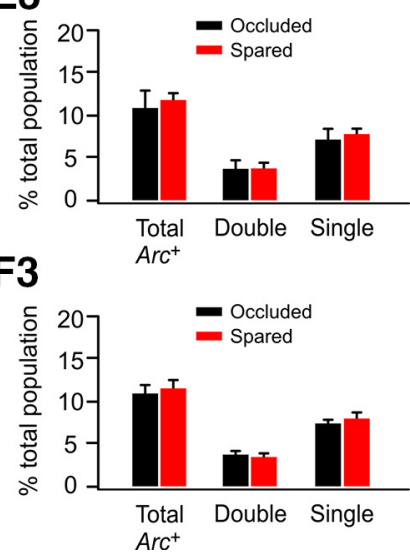

Figure 2. Early odor preference learning stabilizes the mitral cell ensemble to the conditioned odor in the $O B$. $A, S$ chematic of $O B$ anatomy and Arc sampling regions (red rectangles). D, Dorsal; $\mathrm{V}$, ventral; L, lateral; $\mathrm{M}$, medial; $0 \mathrm{~N}$, olfactory nerve; $\mathrm{GL}$, glomerular layer; $\mathrm{MCL}$, mitral cell layer; $\mathrm{GCL}$, granule cell layer. $B 1-B 3,0 / \mathrm{S}^{+}$training leads to increased overlap of mitral cell ensembles in the dorsolateral olfactory bulb responding to $2 \times$ peppermint exposures. $B 1$, Example images of the mitral cell layer in the occluded and spared olfactory bulbs from the same animal. $B 2$, OLR of mitral cell ensembles responding to $2 \times$ peppermint exposures. $B$, Percentage of $\mathrm{ArC}^{+}$cells over the total population indexed by DAPI staining. $\mathrm{C} 1-\mathrm{C}\left(3,0 / \mathrm{S}^{-}\right.$training does not change the $\mathrm{OLR}$ of mitral cell ensembles in the dorsolateral $\mathrm{OB}$ responding to $2 \times$ peppermint exposures. $D 1-D 3,0 / S^{+}$training leads to increased overlap of mitral cell ensembles in the ventromedial $O B$ responding to $2 \times$ peppermint exposures. $E 1-E 3,0 / S^{-}$training does not change the 0 LR of mitral cell ensembles in the ventromedial $O B$ responding to $2 \times$ peppermint exposures. $F 1-F 3,0 / S^{+}$training with peppermint does not change the $0 \mathrm{LR}$ of mitral cell ensembles in the dorsolateral $\mathrm{OB}$ responding to $2 \times$ vanillin exposures. $M C$, Mitral cell; $\mathrm{DL}$, dorsolateral; VM, ventraomedial; PP, peppermint; VA, vanillin. Arrows indicate double-stained $\operatorname{Arc}^{+}$cells. Scale bars, $20 \mu \mathrm{m} .{ }^{*} p<0.05{ }^{* *} p<0.01$.

sion (Fig. 1A). In the present experiments, we were also able to use Arc to examine granule cells, although it is not normally often expressed in inhibitory interneurons (Vazdarjanova et al., 2006; McCurry et al., 2010) and did not occur here in the juxtaglomerular neurons.

Two sets of experiments were included in this study. First, naive rat pups were used to test whether $\operatorname{Arc}$ can serve as an 
input-specific activity marker in the OB. Second, rat pups underwent either odor paired with stroking $\left(\mathrm{O} / \mathrm{S}^{+}\right)$or odor-only $\left(\mathrm{O} / \mathrm{S}^{-}\right)$ training and were given $2 \times$ peppermint or vanillin before brain extractions (Fig. 1A).

\section{Odor input specificity in the OB indexed by Arc mRNA}

To test the odor input specificity of Arc activation, naive pups were exposed to two 5 min episodes of odor: either peppermint on both occasions separated by a $25 \mathrm{~min}$ interval (Fig. 1A, top, PP-PP) or peppermint followed by vanillin $25 \mathrm{~min}$ later (Fig. $1 A$, top, PP-VA). Animals were killed immediately after the second episode and processed for Arc catFISH. Cells that expressed Arc in the cytoplasm only were active during the first odor episode (peppermint) whereas cells that expressed Arc only in the nuclei were active during the second odor episode (peppermint or vanillin), and cells expressing Arc in both the nuclei and cytoplasm were activated by both odor episodes (see example cells in Fig. $1 A$, bottom).

Peppermint activated both mitral cells and granule cells in the $\mathrm{OB}$, especially the dorsolateral and ventromedial regions that were previously shown as "hot spots" for peppermint (Johnson and Leon, 1996; Fig. 1B1). Arc ${ }^{+}$cells in the mitral cell layer were counted in the dorsolateral region of the OB. On average, novel peppermint activated $\sim 7.5 \%$ of the cells in the mitral cell layer of the dorsolateral $\mathrm{OB}$, whereas novel vanillin activated $\sim 6.4 \%$ of the cells in the same region. Comparing the overlap ratio (OLR; the proportion of cells with double staining relative to the total number of $\mathrm{Arc}^{+}$cells) of the cell ensembles activated by two odor events, we demonstrated that repeated peppermint exposure was associated with significantly greater overlap (32.43 \pm $1.64 \%, n=4)$ than peppermint followed by vanillin exposure $(18.73 \pm 2.79 \%, n=4, t=4.23, p=0.006$; Fig. 1B2,B3). This experiment suggests that $A r c$ mRNA can be used as a marker for input-specific representations of odors in the OB. The same odor is more likely to initiate $A r c$ transcription twice in the same cells.

\section{Odor preference training leads to more stable odor representation in the mitral cell layer of the $\mathrm{OB}$}

We next trained rat pups in a multiday (P3-P6) peppermint $\mathrm{O} / \mathrm{S}^{+}$conditioning with a single naris occluded. The ensembles of neurons responding to peppermint in the OB after training were assessed by Arc mRNA expressions induced by two peppermint episodes (Figs. 1A, 2, PP-PP). The trained OB was compared with the occluded side to achieve an intra-animal control. We have shown that single naris occlusion during multiday training leads to lateralized learning and synaptic changes that are confined to the spared olfactory hemisphere (Yuan and Harley, 2012; Fontaine et al., 2013). O/S ${ }^{-}$pups were used as controls to test for any nonspecific effects of repeated odor exposure training.

In the dorsolateral region, the OLR of mitral cell ensembles in the spared $\mathrm{OB}$ in the $\mathrm{O} / \mathrm{S}^{+}$rats was significantly greater $(49.01 \pm$ $0.79 \%)$ than in the occluded bulb $(24.56 \pm 1.48 \%, n=4, t=$ $24.84, p=1.43 \mathrm{E}^{-4}$; Fig. 2 B1,B2). After associative learning, mitral cells are activated more reliably by peppermint odor, and the same cell is likely to respond to both episodes of peppermint. Interestingly, the total number of $\mathrm{Arc}^{+}$cells activated by two odor events did not change in the spared bulb (11.58 $\pm 1.39 \%)$ compared with the occluded one $(12.05 \pm 1.72 \%, n=4, t=0.276$, $p=0.80$; Fig. 2B3). However, double-stained $\mathrm{Arc}^{+}$cells were significantly increased after $\mathrm{O} / \mathrm{S}^{+}$learning $(5.67 \pm 0.69 \%$ in the spared bulb vs $3.01 \pm 0.57 \%$ in the occluded bulb; $n=4, t=4.29$, $p=0.02$; Fig. 2B3). The percentage of single-stained $\mathrm{Arc}^{+}$cells responding to either episode of peppermint showed a trend toward decreasing in the spared OB but did not reach statistical significance $(5.91 \pm 0.72 \%$ in the spared bulb vs $9.04 \pm 1.19 \%$ in the occluded bulb; $n=4, t=2.75, p=0.07)$. The increase in double cells that are likely strongly activated by peppermint suggests odor preference learning in rat pups results in the potentiation of previously weakly activated cells.

The OLR for $\mathrm{O} / \mathrm{S}^{-}$rats was not different between the two bulbs (spared, $33.65 \pm 0.93 \%$; occluded, $34.22 \pm 2.42 \% ; n=3$, $t=0.17, p=0.88$; Fig. 2C1,C2), suggesting no effect of odor exposure itself on initial odor ensemble representation. Consistently, no differences were observed in the numbers of cells expressing Arc in any compartment (Fig. 2C3).

Peppermint representation in the ventromedial OB revealed the same trends. In the $\mathrm{O} / \mathrm{S}^{+}$pups, the OLR of mitral cell ensembles was greater in the spared OB $(45.07 \pm 3.59 \%)$ than in the occluded bulb $(24.40 \pm 2.22 \% ; n=4, t=5.49, p=0.01$; Fig. $2 D 1, D 2)$. Consistent with the dorsolateral region, the doublestained $\mathrm{Arc}^{+}$cells increased after O/S ${ }^{+}$learning (6.26 $\pm 1.52 \%$ in the spared bulb vs $2.57 \pm 0.34 \%$ in the occluded bulb; $n=4, t=$ 3.07, $p=0.05$; Fig. 2D3), whereas the total $\mathrm{Arc}^{+}$cells and singlestained $\mathrm{Arc}^{+}$cells were not different in the two bulbs (Fig. 2D3). In $\mathrm{O} / \mathrm{S}^{-}$pups, neither the OLR of cell ensembles (Fig. 2E1,E2) nor the numbers of $\mathrm{Arc}^{+}$cells (Fig. 2E3) are different in the ventromedial $\mathrm{OB}$.

An unexpected outcome was a significant reduction in the OLR of the peppermint representation in the occluded OB in the $\mathrm{O} / \mathrm{S}^{+}$group compared with that in the $\mathrm{O} / \mathrm{S}^{-}$group $(t=3.60, p=$ 0.02 , unpaired $t$ test). This may relate to a backward conditioning effect when the naris plug was removed and residual peppermint odor remained on the pup. Such an effect might be expected to reduce the stability of peppermint encoding.

\section{Mitral cell ensemble stabilization is specific to the conditioned odor}

In another set of experiments, we examined dorsolateral $\mathrm{OB}$ $\mathrm{Arc}^{+}$mitral cell ensembles to vanillin after $\mathrm{O} / \mathrm{S}^{+}$training with peppermint (Fig. $2 F)$. The OLR $(29.48 \pm 1.71 \%$ in the spared bulb vs $33.14 \pm 0.85 \%$ in the occluded bulb; $n=5, t=2.19, p=$ 0.10; Fig. $2 F 1, F 2$ ) and the pattern of Arc expression (Fig. 2F3) were not different between the spared and occluded bulbs. This demonstrates that odor learning is input specific in the OB such that only the representation of the conditioned odor is altered.

\section{Odor preference training also results in a more stable odor representation in the underlying granule cells of the $O B$}

We next compared the granule cell ensembles in the OB granule cell layer after $\mathrm{O} / \mathrm{S}^{+}$training. The areas of interest were taken from the same rectangle regions where we measured cell ensembles in the mitral cell layers. Granule cell ensembles in the dorsolateral region showed greater OLR in the spared OB $(48.07 \pm$ 2.99) compared with the occluded $\mathrm{OB}(24.40 \pm 2.43 ; n=4, t=$ $4.56, p=0.02$; Fig. $3 A 1, A 2)$. The total $\mathrm{Arc}^{+}$cells $(7.25 \pm 0.32 \%$ in the spared bulb vs $8.31 \pm 1.60 \%$ in the occluded bulb; $n=4, t=$ $0.60, p=0.59)$ and double-stained $\mathrm{Arc}^{+}$cells $(7.25 \pm 0.32 \%$ in the spared bulb vs $8.31 \pm 1.60 \%$ in the occluded bulb; $n=4, t=$ $0.60, p=0.59$; Fig. $3 A 3$ ) were not different in the two OBs. However, the single-stained $\mathrm{Arc}^{+}$cells showed a trend of decreased numbers in the spared $\mathrm{OB}(3.76 \pm 0.21)$ compared with the occluded $\mathrm{OB}(6.20 \pm 1.01 ; n=4, t=2.67, p=0.076$; Fig. $3 A 3)$. There were no differences in either OLR or $\mathrm{Arc}^{+}$cell numbers in the ventromedial region of the $\mathrm{OB}$ (Fig. 3B1-B3). Changes in granule cell ensembles are also training odor specific. Neither 
the OLR nor numbers of $\mathrm{Arc}^{+}$cells were different in the spared and occluded $O B$ in the dorsolateral regions to the control odor vanillin (Fig. 3C1-C3).

\section{A more stable odor map in the aPC}

We have previously shown that the $\mathrm{OB}$ and the aPC are both involved in, and support, early odor preference learning (Lethbridge et al., 2012; Yuan and Harley, 2012; Fontaine et al., 2013; Morrison et al., 2013). We examined pyramidal cell ensemble changes in the aPC after early odor preference learning from the same animals as in the OB experiments. Singleodor exposure activates $\sim 1 \%$ pyramidal cells in the aPC. Similar to mitral cell ensembles in the OB, the stability of the odor representation as indexed by the OLR of pyramidal ensembles in the spared aPC $(35.74 \pm 2.38 \%)$ was significantly greater than that in the occluded one (18.44 \pm $2.62 \% ; n=4, t=7.84, p=0.004$; Fig. $4 B 1, B 2)$. The increase in the overlap ratio was caused by an increased number of double-stained $\mathrm{Arc}^{+}$pyramidal cells $(0.75 \pm 0.12 \%$ in the spared hemisphere vs $0.45 \pm 0.12 \%$ in the occluded side; $n=$ $4, t=3.45, p=0.04)$, whereas the total number of $\mathrm{Arc}^{+}$cells to two odor events and the single-stained $\mathrm{Arc}^{+}$cells were not different in two hemispheres (Fig. 4B3). Odor experience alone did not alter either the overlap of the two peppermint ensembles (Fig. 4C1,C2) or the numbers of $\mathrm{Arc}^{+}$cells activated (Fig. 4C3).

\section{Discussion}

\section{The nature of representations}

Cortical representations are known to be both sparse, reflecting a dynamic balance of excitatory and inhibitory inputs, and variable (Shadlen and Newsome, 1998; Olshausen and Field, 2004). These characteristics are thought to account for the large storage capacity of mammalian brain and reflect the dynamic aspects of its operation. Although representation in the $\mathrm{OB}$ itself is more like that of sensory cortices in having a spatial organization such that we are able to target representational regions, the aPC behaves like the general associative cortical model (Johnson et al., 2000). Compared with adult aPC (Shakhawat et al., 2014), the odor ensembles in rat pup aPC were significantly smaller $(\sim 3 \%$ vs $\sim 1 \%)$. We suggest this difference relates directly to the maturation of lateral olfactory tract input to the piriform cortex, which is about onethird of the adult value at this age (Sarma et al., 2011). Earlier estimates of piriform ensemble size have been substantially larger (Poo and Isaacson, 2009; Stettler and Axel, 2009), but this is likely a function of probing ensembles in the anesthetized versus awake state (Kato et al., 2012). The present values derive from ensemble measurements in awake animals.

Rat pups have similar numbers of piriform pyramidal cells as the adult (Sarma et al., 2011), and so dividing total piriform stereological counts (Capurso et al., 1997; Duffell et al., 2000) in half provides an estimate of $\sim 150,000$ cells available in each hemisphere to participate in aPC representations. Thus, a $1 \%$
A2

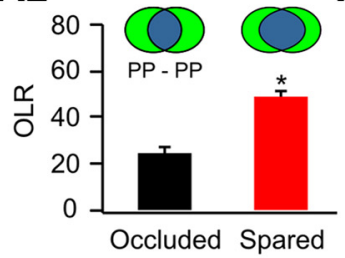

A3

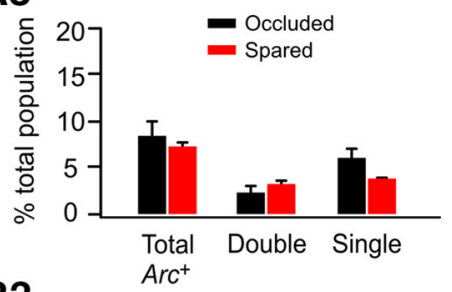

B2

B3
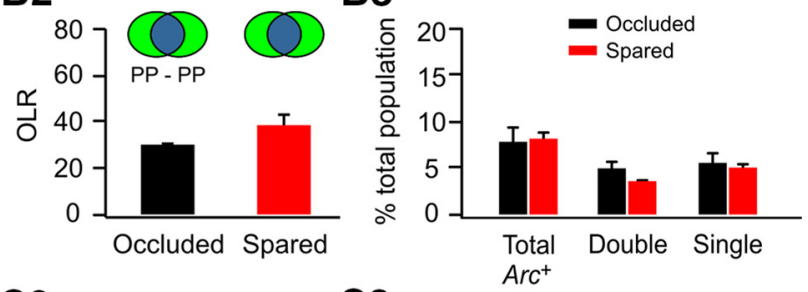

C2

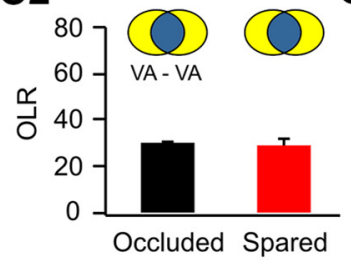

C3

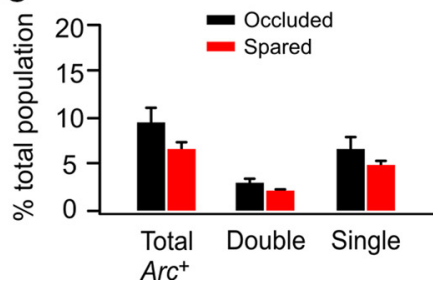

Figure 3. Early odor preference learning stabilizes the granule cell ensemble to the conditioned odor in the $0 \mathrm{~B} . \mathbf{A 1 - A 3 , 0 / \mathrm { S } ^ { + }}$ ing leads to increased overlap of granule cell ensembles in the dorsolateral olfactory bulb responding to $2 \times$ peppermin ensembles at the dorsolateral $\mathrm{OB}$ responding to $2 \times$ vanillin exposures. $\mathrm{GC}$, Granule cell; DL, dorsolateral; VM, ventromedial; PP peppermint; VA, vanillin. Arrows indicate double-stained $\operatorname{Arc}^{+}$cells. Scale bars, $20 \mu \mathrm{m} .{ }^{*} p<0.05$.

representation $(\sim 1500$ cells $)$ is well above the calculated threshold of 500 piriform pyramidal cells required to reliably drive odor preference behavior (Choi et al., 2011) and identical to the percentage of Kenyon cells estimated to underlie odor ensembles in the mushroom body of the insect (Campbell et al., 2013). It would be interesting if ensemble size was conserved in nervous system evolution.

A curious aspect of the present data is the finding of an $\sim 15-$ $20 \%$ overlap among unrelated odors, which is substantially larger than a $0.5 \%$ overlap that would be predicted from the size of each odor's representation $(\sim 7 \%)$ by random draw with replacement. We suggest that this overlap reflects the existence of an active subset of cortical neurons that are primed to participate in any representation in a given time window (Yassin et al., 2010; Luczak and Maclean, 2012; Mizuseki and Buzsaki, 2013; Klinshov et al., 2014). Such primed subsets require a reconfiguration of our normal thinking about distributed random neural networks.

The first conclusion that can be made about granule cell participation in odor ensembles from these data is that it appears to be odor specific, arguing for different mitral cell/granule cell ensembles for different odors. Johnson and Leon (1996), using 2-deoxyglucose (2-DG), showed that peppermint activates two hot spots in the glomerular layer of the $\mathrm{OB}$, one in the dorsolateral region and one in the ventromedial region. Early preference learning predominately enhanced 2-DG activation in the dorsolateral glomerular region (Johnson and Leon, 1996) and phosphorylated CREB in the dorsolateral mitral cell layer (McLean et al., 1999), consistent with the more prominent change in the Arc expression of mitral and granule cells in dorsolateral region. In 


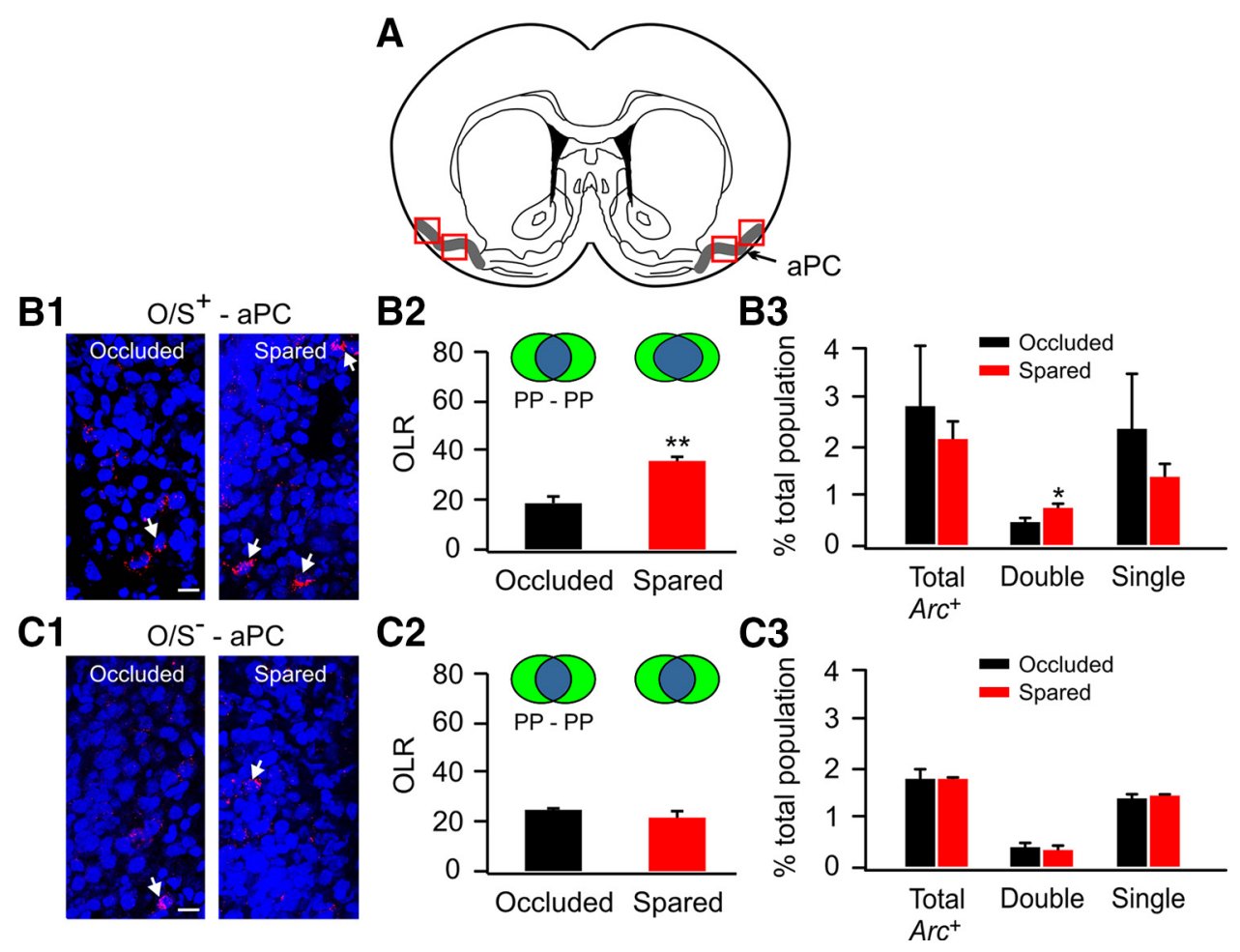

Figure 4. Early odor preference learning stabilizes the odor map for the conditioned odor in the aPC. $A$, Schematic of aPC and $\operatorname{Arcsampling~regions~(red~rectangles).~} B 1-B 3,0 / S^{+}$training leads to increased overlap of pyramidal cell ensembles in the aPC responding to $2 \times$ peppermint exposures. $\boldsymbol{B} 1$, Example images of the pyramidal cell layer in the occluded and spared aPC from the same animal. B2, OLR of pyramidal cell ensembles responding to $2 \times$ peppermint exposures. $B 3$, Percentage of $\mathrm{Arc}^{+}{ }^{+}$cells over the total population indexed by DAPI staining. C1-C3, $0 / \mathbf{S}^{-}$training does not change the $0 \mathrm{LR}$ of pyramidal cell ensembles in the aPC responding to $2 \times$ peppermint exposures. PP, Peppermint. Arrows indicate double-stained $\mathrm{Arc}^{+}$cells. Scale bars, $20 \mu \mathrm{m}$. ${ }^{*} p<0.05$; ${ }^{* *} p<0.01$

19-d-old rats, c-Fos granule cells significantly decrease with odor learning (Woo et al., 1996), as do $\mathrm{Arc}^{+}$pyramidal cells in piriform cortex of adult rats (Shakhawat et al., 2014). The lack of a decrease here in either area is likely related to age.

The second conclusion is that, like mitral cells, the granule cell representation of an odor increases its stability after the pairing with stroking reward. This parallel change in the granule cell and mitral cell ensembles is consistent with the idea that changes in excitation in any cortical system will be accompanied by balanced inhibition (Isaacson and Scanziani, 2011; Saar et al., 2012; Xue et al., 2014). Mitral cells driving granule cells provides the most parsimonious account of these effects, and if that is the case, it again underlines a highly selective relationship among mitral and granule cells. Consistent with such selectivity, electrical coupling between mitral cells and nearby underlying granule cells has been reported in rat pups (Paternostro et al., 1995). Feedback effects from aPC that drive granule cell inhibition for individual odors has also been demonstrated (Restrepo et al., 2009; Boyd et al., 2012) and is another possible source of support for the parallel stability increases observed in the granule cell ensembles.

Overall, the striking feature of the learning-related changes in odor representation observed in these experiments is the increase in the stability of ensemble representation from $~ 25 \%$ to $49 \%$ in the $\mathrm{OB}$ and from $\sim 18 \%$ to $\sim 35 \%$ in the aPC. The level of overlap after our odor reward pairings in the $\mathrm{OB}$ is similar to what has been observed using Arc to identify representations of repeated strong visual input in secondary visual cortex (50\% overlap; Rudinskiy et al., 2012). This similarity of overlap levels in sensory stimuli for rewarded odor and for strong visual stimulation is consistent with data showing odor learning modifies OB responses to be similar to responses to a higher concentration of odorant (Abraham et al., 2014). Recent modeling work on cortical system representations argues that the stability parameter in population vectors is critical for adaptive behavior (Montijn et al., 2014). These changes in the responses to simple odorants were not able to be previously characterized using electrophysiological methods to probe representations (Chapuis and Wilson, 2012).

\section{Generality of the rat pup model}

There are many parallels between the rat pup odor preference model and adult odor associative learning models. Adult aPC ensembles also show the stabilization effect of learning and memory, but the number of neurons participating in an ensemble becomes somewhat sparser than before learning (Shakhawat et al., 2014), whereas that number did not change in the rat pup. In neither model does enlargement of the rewarded representation occur; this is consistent with data suggesting enlargement of sensory representations does not account for long-term memory even when it is seen (Reed et al., 2011). However, multiple groups have reported enlarged $\mathrm{OB}$ glomerular representations with learning in both rodent pups and adults (Woo et al., 1987; Johnson and Leon, 1996; Abraham et al., 2014). We have also described such a glomerular effect using intrinsic optical imaging in the odor preference learning model (Yuan et al., 2002), and as mentioned earlier, these effects are similar to those of increasing concentrations of the odorant (Abraham et al., 2014). Both enhanced glomerular input and increased stability of principal neuronal network representations should serve to create a stronger and more discriminable experiential input.

The machinery for NE to act as an unconditioned stimulus in the rat pup (Yuan et al., 2014) remains in the OB of older rats, and recent data suggest that blocking both $\alpha$-and $\beta$-adrenoceptors 
in the adult $\mathrm{OB}$ prevents discrimination of similar odors (Doucette et al., 2007; Mandairon et al., 2008). Whereas NE via $\beta$-adrenoceptor activation also mediates early odor learning in rat pup aPC (Morrison et al., 2013), as in rat pup OB, the role of NE projections and the function of NE in the aPC in adult rat odor learning requires future investigation. NMDARs and L-type calcium channels are critical in the $\mathrm{OB}$ as calcium sources mediating plasticity (Jerome et al., 2012; Lethbridge et al., 2012), and they are likely involved in aPC plasticity and aPC-mediated learning (Morrison et al., 2013), as both NMDARs and L-type calcium channels are critical mediators for Arc activation in the hippocampus (Bateup et al., 2013).

The cellular and intracellular supports of rat pup learning and memory (see Introduction) are also those implicated in invertebrate and vertebrate associative learning and appear central for learning and memory in mammalian brain across the life span.

\section{Arc and plasticity}

$A r c$ here identifies the neurons participating in responding to odors, with the advantage of capturing the ensembles to the same odor twice. Neurons either alter their firing rate or increase their firing reliability to an odor after learning (Doucette et al., 2011). Increases in neuronal firing reliability translate into a tighter overlap in the condition in which an animal receives the same odor twice. Our data from both rat pups and adults (Shakhawat et al., 2014) suggest that the probability that weakly activated cells transcribe Arc twice is lower before conditioning than after.

$A r c$ is also part of the plasticity story. Others have suggested that CREB and/or immediate-early genes like Arc identify neurons that are primed to participate in memory ensembles (Han et al., 2007; Yiu et al., 2014). Arc has recently been shown to promote thin spine production as sites for connectivity strengthening while homeostatically downregulating weaker connections (Peebles et al., 2010). Arc-negative mice show neither depression nor potentiation as a function of visual experience, whereas with olfactory experience, both potentiation and depression operate and are hypothesized to modulate the aPC ensemble changes across pups and adults (Saar et al., 2012; Yuan et al., 2014). Thin spine growth, as reported in hippocampus, may contribute to lasting ensemble strengthening in $\mathrm{aPC}$, as well as among $\mathrm{OB}$ granule cells.

\section{References}

Abraham NM, Vincis R, Lagier S, Rodriguez I, Carleton A (2014) Long term functional plasticity of sensory inputs mediated by olfactory learning. Elife (Cambridge) 3:e02109. CrossRef Medline

Bateup HS, Denefrio CL, Johnson CA, Saulnier JL, Sabatini BL (2013) Temporal dynamics of a homeostatic pathway controlling neural network activity. Front Mol Neurosci 6:28. CrossRef Medline

Boyd AM, Sturgill JF, Poo C, Isaacson JS (2012) Cortical feedback control of olfactory bulb circuits. Neuron 76:1161-1174. CrossRef Medline

Campbell RA, Honegger KS, Qin H, Li W, Demir E, Turner GC (2013) Imaging a population code for odor identity in the Drosophila mushroom body. J Neurosci 33:10568-10581. CrossRef Medline

Capurso SA, Calhoun ME, Sukhov RR, Mouton PR, Price DL, Koliatsos VE (1997) Deafferentation causes apoptosis in cortical sensory neurons in the adult rat. J Neurosci 17:7372-7384. Medline

Chapuis J, Wilson DA (2012) Bidirectional plasticity of cortical pattern recognition and behavioral sensory acuity. Nat Neurosci 15:155-161. CrossRef Medline

Choi GB, Stettler DD, Kallman BR, Bhaskar ST, Fleischmann A, Axel R (2011) Driving opposing behaviors with ensembles of piriform neurons. Cell 146:1004-1015. CrossRef Medline

Cui W, Smith A, Darby-King A, Harley CW, McLean JH (2007) A temporalspecific and transient cAMP increase characterizes odorant classical conditioning. Learn Mem 14:126-133. CrossRef Medline
Cui W, Darby-King A, Grimes MT, Howland JG, Wang YT, McLean JH, Harley CW (2011) Odor preference learning and memory modify GluA1 phosphorylation and GluA1 distribution in the neonate rat olfactory bulb: testing the AMPA receptor hypothesis in an appetitive learning model. Learn Mem 18:283-291. CrossRef Medline

Doucette W, Milder J, Restrepo D (2007) Adrenergic modulation of olfactory bulb circuitry affects odor discrimination. Learn Mem 14:539-547. CrossRef Medline

Doucette W, Gire DH, Whitesell J, Carmean V, Lucero MT, Restrepo D (2011) Associative cortex features in the first olfactory brain relay station. Neuron 69:1176-1187. CrossRef Medline

Duffell SJ, Soames AR, Gunby S (2000) Morphometric analysis of the developing rat brain. Toxicol Pathol 28:157-163. CrossRef Medline

Fontaine CJ, Harley CW, Yuan Q (2013) Lateralized odor preference training in rat pups reveals an enhanced network response in anterior piriform cortex to olfactory input that parallels extended memory. J Neurosci 33: 15126-15131. CrossRef Medline

Grimes MT, Harley CW, Darby-King A, McLean JH (2012) PKA increases in the olfactory bulb act as unconditioned stimuli and provide evidence for parallel memory systems: pairing odor with increased PKA creates intermediate- and long-term, but not short-term, memories. Learn Mem 19:107-115. CrossRef Medline

Guzowski JF, Worley PF (2001) Cellular compartment analysis of temporal activity by fluorescence in situ hybridization (catFISH). Curr Protoc Neurosci Chapter 1:Unit 18. CrossRef Medline

Guzowski JF, Timlin JA, Roysam B, McNaughton BL, Worley PF, Barnes CA (2005) Mapping behaviorally relevant neural circuits with immediateearly gene expression. Curr Opin Neurobiol 15:599-606. CrossRef Medline

Han JH, Kushner SA, Yiu AP, Cole CJ, Matynia A, Brown RA, Neve RL, Guzowski JF, Silva AJ, Josselyn SA (2007) Neuronal competition and selection during memory formation. Science 316:457-460. CrossRef Medline

Harley CW, Darby-King A, McCann J, McLean JH (2006) Beta1adrenoceptor or alphal-adrenoceptor activation initiates early odor preference learning in rat pups: support for the mitral cell/cAMP model of odor preference learning. Learn Mem 13:8-13. CrossRef Medline

Isaacson JS, Scanziani M (2011) How inhibition shapes cortical activity. Neuron 72:231-243. CrossRef Medline

Jerome D, Hou Q, Yuan Q (2012) Interaction of NMDA receptors and L-type calcium channels during early odor preference learning in rats. Eur J Neurosci 36:3134-3141. CrossRef Medline

Johnson BA, Leon M (1996) Spatial distribution of [14C]2-deoxyglucose uptake in the glomerular layer of the rat olfactory bulb following early odor preference learning. J Comp Neurol 376:557-566. CrossRef Medline

Johnson DM, Illig KR, Behan M, Haberly LB (2000) New features of connectivity in piriform cortex visualized by intracellular injection of pyramidal cells suggest that "primary" olfactory cortex functions like "association" cortex in other sensory systems. J Neurosci 20:6974-6982. Medline

Kato HK, Chu MW, Isaacson JS, Komiyama T (2012) Dynamic sensory representations in the olfactory bulb: modulation by wakefulness and experience. Neuron 76:962-975. CrossRef Medline

Klinshov VV, Teramae JN, Nekorkin VI, Fukai T (2014) Dense neuron clustering explains connectivity statistics in cortical microcircuits. PLoS One 9:e94292. CrossRef Medline

Kucharski D, Hall WG (1987) New routes to early memories. Science 238: 786-788. CrossRef Medline

Kucharski D, Johanson IB, Hall WG (1986) Unilateral olfactory conditioning in 6-day-old rat pups. Behav Neural Biol 46:472-490. CrossRef Medline

Lethbridge R, Hou Q, Harley CW, Yuan Q (2012) Olfactory bulb glomerular NMDA receptors mediate olfactory nerve potentiation and odor preference learning in the neonate rat. PLoS One 7:e35024. CrossRef Medline

Logan DW, Brunet LJ, Webb WR, Cutforth T, Ngai J, Stowers L (2012) Learned recognition of maternal signature odors mediates the first suckling episode in mice. Curr Biol 22:1998-2007. CrossRef Medline

Luczak A, Maclean JN (2012) Default activity patterns at the neocortical microcircuit level. Front Integr Neurosci 6:30. CrossRef Medline

Lyford GL, Yamagata K, Kaufmann WE, Barnes CA, Sanders LK, Copeland NG, Gilbert DJ, Jenkins NA, Lanahan AA, Worley PF (1995) Arc, a growth factor and activity-regulated gene, encodes a novel cytoskeleton- 
associated protein that is enriched in neuronal dendrites. Neuron 14:433445. CrossRef Medline

Mandairon N, Peace S, Karnow A, Kim J, Ennis M, Linster C (2008) Noradrenergic modulation in the olfactory bulb influences spontaneous and reward-motivated discrimination, but not the formation of habituation memory. Eur J Neurosci 27:1210-1219. CrossRef Medline

McCurry CL, Shepherd JD, Tropea D, Wang KH, Bear MF, Sur M (2010) Loss of Arc renders the visual cortex impervious to the effects of sensory experience or deprivation. Nat Neurosci 13:450-457. CrossRef Medline

McLean JH, Harley CW, Darby-King A, Yuan Q (1999) pCREB in the neonate rat olfactory bulb is selectively and transiently increased by odor preference-conditioned training. Learn Mem 6:608-618. CrossRef Medline

Miyashita T, Kubik S, Haghighi N, Steward O, Guzowski JF (2009) Rapid activation of plasticity-associated gene transcription in hippocampal neurons provides a mechanism for encoding of one-trial experience. J Neurosci 29:898-906. CrossRef Medline

Mizuseki K, BuzsákiG (2013) Preconfigured, skewed distribution of firing rates in the hippocampus and entorhinal cortex. Cell Rep 4:1010-1021. CrossRef Medline

Montijn JS, Vinck M, Pennartz CM (2014) Population coding in mouse visual cortex: response reliability and dissociability of stimulus tuning and noise correlation. Front Comput Neurosci 8:58. CrossRef Medline

Morrison GL, Fontaine CJ, Harley CW, Yuan Q (2013) A role for the anterior piriform cortex in early odor preference learning: evidence for multiple olfactory learning structures in the rat pup. J Neurophysiol 110:141-152. CrossRef Medline

Olshausen BA, Field DJ (2004) Sparse coding of sensory inputs. Curr Opin Neurobiol 14:481-487. CrossRef Medline

Paternostro MA, Reyher CK, Brunjes PC (1995) Intracellular injections of Lucifer yellow into lightly fixed mitral cells reveal neuronal dye-coupling in the developing rat olfactory bulb. Brain Res Dev Brain Res 84:1-10. CrossRef Medline

Peebles CL, Yoo J, Thwin MT, Palop JJ, Noebels JL, Finkbeiner S (2010) Arc regulates spine morphology and maintains network stability in vivo. Proc Natl Acad Sci U S A 107, 18173-18178. CrossRef Medline

Poo C, Isaacson JS (2009) Odor representations in olfactory cortex: "sparse" coding, global inhibition, and oscillations. Neuron 62:850-861. CrossRef Medline

Rangel S, Leon M (1995) Early odor preference training increases olfactory bulb norepinephrine. Brain Res Dev Brain Res 85:187-191. CrossRef Medline

Reed A, Riley J, Carraway R, Carrasco A, Perez C, Jakkamsetti V, Kilgard MP (2011) Cortical map plasticity improves learning but is not necessary for improved performance. Neuron 70:121-131. CrossRef Medline

Restrepo D, Doucette W, Whitesell JD, McTavish TS, Salcedo E (2009) From the top down: flexible reading of a fragmented odor map. Trends Neurosci 32:525-531. CrossRef Medline

Rudinskiy N, Hawkes JM, Betensky RA, Eguchi M, Yamaguchi S, Spires-Jones TL, Hyman BT (2012) Orchestrated experience-driven Arc responses are disrupted in a mouse model of Alzheimer's disease. Nat Neurosci 15:1422-1429. CrossRef

Rumsey JD, Darby-King A, Harley CW, McLean JH (2001) Infusion of the metabotropic receptor agonist, DCG-IV, into the main olfactory bulb induces olfactory preference learning in rat pups. Brain Res Dev Brain Res 128:177-179. CrossRef Medline
Saar D, Reuveni I, Barkai E (2012) Mechanisms underlying rule learninginduced enhancement of excitatory and inhibitory synaptic transmission. J Neurophysiol 107:1222-1229. CrossRef

Sarma AA, Richard MB, Greer CA (2011) Developmental dynamics of piriform cortex. Cereb Cortex 21:1231-1245. CrossRef Medline

Shadlen MN, Newsome WT (1998) The variable discharge of cortical neurons: implications for connectivity, computation, and information coding. J Neurosci 18:3870-3896. Medline

Shakhawat AM, Harley CW, Yuan Q (2012) Olfactory bulb alpha2adrenoceptor activation promotes rat pup odor-preference learning via a cAMP-independent mechanism. Learn Mem 19:499-502. CrossRef Medline

Shakhawat AM, Harley CW, Yuan Q (2014) Arc visualization of odor objects reveals experience-dependent ensemble sharpening, separation, and merging in anterior piriform cortex in adult rat. J Neurosci 34:1020610210. CrossRef Medline

Stettler DD, Axel R (2009) Representations of odor in the piriform cortex. Neuron 63:854-864. CrossRef Medline

Sullivan RM, Stackenwalt G, Nasr F, Lemon C, Wilson DA (2000) Association of an odor with activation of olfactory bulb noradrenergic betareceptors or locus coeruleus stimulation is sufficient to produce learned approach responses to that odor in neonatal rats. Behav Neurosci 114: 957-962. CrossRef Medline

Vazdarjanova A, Ramirez-Amaya V, Insel N, Plummer TK, Rosi S, Chowdhury S, Mikhael D, Worley PF, Guzowski JF, Barnes CA (2006) Spatial exploration induces ARC, a plasticity-related immediate-early gene, only in calcium/calmodulin-dependent protein kinase II-positive principal excitatory and inhibitory neurons of the rat forebrain. J Comp Neurol 498: 317-329. CrossRef Medline

Woo CC, Coopersmith R, Leon M (1987) Localized changes in olfactory bulb morphology associated with early olfactory learning. J Comp Neurol 263:113-125. CrossRef Medline

Woo CC, Oshita MH, Leon M (1996) A learned odor decreases the number of Fos-immunopositive granule cells in the olfactory bulb of young rats. Brain Res 716:149-156. CrossRef Medline

Xue M, Atallah BV, Scanziani M (2014) Equalizing excitation-inhibition ratios across visual cortical neurons. Nature 511:596-600. CrossRef Medline

Yassin L, Benedetti BL, Jouhanneau JS, Wen JA, Poulet JF, Barth AL (2010) An embedded subnetwork of highly active neurons in the neocortex. Neuron 68:1043-1050. CrossRef Medline

Yiu AP, Mercaldo V, Yan C, Richards B, Rashid AJ, Hsiang HL, Pressey J, Mahadevan V, Tran MM, Kushner SA, Woodin MA, Frankland PW, Josselyn SA (2014) Neurons are recruited to a memory trace based on relative neuronal excitability immediately before training. Neuron 83 : 722-735. CrossRef Medline

Yuan Q, Harley CW (2012) What a nostril knows: olfactory nerve-evoked AMPA responses increase while NMDA responses decrease at 24 -h posttraining for lateralized odor preference memory in neonate rat. Learn Mem 19:50-53. CrossRef Medline

Yuan Q, Harley CW, McLean JH, Knöpfel T (2002) Optical imaging of odor preference memory in the rat olfactory bulb. J Neurophysiol 87:31563159. CrossRef Medline

Yuan Q, Shakhawat AM, Harley CW (2014) Mechanisms underlying early odor preference learning in rats. Prog Brain Res 208:115-156. CrossRef Medline 